\title{
- LITERATURA PIĘKNA NA CZAS STUDIOWANIA W PANDEMII
}

\section{FICTION FOR STUDENTS DURING THE PANDEMIC}

\author{
Kamil Konrad Hozyasz \\ Wydział Nauk o Zdrowiu, Państwowa Szkoła Wyższa im. Papieża Jana Pawła II w Białej Podlaskiej \\ https://orcid.org/0000-0001-8606-2509
}

DOI: https://doi.org/10.20883/pielpol.2021.14

\begin{abstract}
STRESZCZENIE
Pandemia COVID-19 powoduje bezprecedensowe cierpienia na całym świecie i stanowi wyzwanie dla gospodarki. Codzienne życie ludzi opiera się na interakcjach społecznych, co jest szczególnie łatwo dostrzegalne w społecznościach studenckich. Pandemia, wywołana przez wirusa SARS-CoV-2, stawia studentów pielęgniarstwa i ratownictwa medycznego wobec nowych dodatkowych wyzwań. Z jednej strony na ich oczach nastąpiło społeczne dowartościowanie zawodów, które wkrótce będą wykonywali, a z drugiej strony obserwują nieprzygotowanie sektora ochrony zdrowia do walki z pandemią. Dotychczas tych studentów nauczano medycyny, pojmowanej przede wszystkim jako obszerny zasób niepodważalnej wiedzy do wykorzystania niż inkubator poszukiwań. Katastroficzne następstwa pandemii wynikają m.in. z jej nieprzewidywalności, co dobitnie uwidaczniają twórcy literatury pięknej. Celem artykułu było przedstawienie wybranych dzieł literackich z motywem plagi bakteryjnej lub wirusowej. „Szkarłatna dżuma” Londona jest warta przeczytania chociażby dla zyskania nowej perspektywy wobec COVID-19. Dyskusja o wybranych dziełach literatury pięknej może pomóc w przywracaniu równowagi zaburzonej przez pandemię oraz ubogacać zarówno akademików jak i ich studentów.
\end{abstract}

SŁOWA KLUCZOWE: studenci pielęgniarstwa, dzieła literackie, motyw katastroficznej epidemii, pandemia COVID-19.

\section{Doświadczenie nieprzewidywalności i chaosu rekomendacji przeciwepidemicznych}

Pandemia wywołana przez wirusa SARS-CoV-2 stanowi szczególne wyzwanie dla każdego człowieka indywidualnie, obejmując rozważania czy zachoruję ja, moi najbliżsi i jaki będzie przebieg choroby a w przypadku jej ciężkiego wariantu, czy przeżyję i z jakimi powikłaniami, oraz sektora ochrony zdrowia, przedsiębiorców i polityków [1]. Studenci kierunków medycznych, jak wszyscy inni uczący się, musieli odnaleźć się w nowej rzeczywistości ze zdalną edukacją. Frustrację budziły harce tzw. anty-COVID-owców i równoczasowo zmieniające się zalecenia odnośnie zapobiegania przenoszeniu się wirusa SARS-CoV-2. Maseczki zakrywające nos i usta na poszczególnych etapach pandemii w 2020 r. zabezpie-

\begin{abstract}
The COVID-19 pandemic has caused unprecedented suffering throughout the world, as well as economic challenges. The everyday life of humans is based on the social character of our species, which is especially evident in the student community. The COVID-19 pandemic has also created new challenges for nursing and medical rescue students. On the one hand, they observe the appreciation of the professions they will soon be doing, and on the other hand, they observe the unpreparedness of the health sector to fight the pandemic. So far, these groups of students have been presented with medicine as a vast resource of knowledge to be used rather than a search incubator. The catastrophic nature of the pandemic results, inter alia, from its unpredictability, which is perfectly illustrated by literary visions of a raging plague. The objective of this paper is to take a look at fictional stories with the motive of catastrophic bacterial or viral infections. London's "The Scarlet Plague" is worth reading again since COVID-19 can be considered our plague. Selected literature works for a guided discussion, in general, may help to restore balance, and make us all, academics and our students, wiser, better persons.
\end{abstract}

KEYWORDS: nursing students, literature works, catastrophic epidemic theme, COVID-19 pandemic.

czały, były zbędne i ponownie stanowiły obowiązkowy wymóg zwiększenia bezpieczeństwa przy wychodzeniu z domu. Skupisk ludzkich należało bezwzględnie unikać, potem nastał czas dopuszczalności planowych wielopokoleniowych i zarazem wielogodzinnych biesiad, a następnie jedynym rozwiązaniem przy katastroficznym trendzie wzrostu liczby chorych na COVID-19 wymagających tlenoterapii i wentylacji mechanicznej stał się częściowy lock-down. Autor jako nauczyciel akademicki był adresatem pytań studentów kierunków medycznych o osąd brytyjskiej koncepcji niewprowadzania ograniczeń dla społeczeństwa i liczenia na osiągnięcie odporności populacyjnej (mało empatycznie nazywanej stadną) wiosną 2020 r. Wśród młodych ludzi pojawiał się bezwarunkowy protest przeciwko kursowi brytyjskiego 
premiera na przeciążenie sektora zdrowotnego i niejako przyzwolenie na śmierć ludzi, jak się wtedy wydawało prawie wyłącznie starych i schorowanych, którym nie będzie można pomóc z powodu braku wolnych miejsc w szpitalach. Apele polityków-medyków o powstrzymanie się obywateli od podróży w połączeniu z ujawnianymi w mass mediach ich prywatnymi zagranicznymi wojażami deprecjonują zarządzających kryzysem.

Studenci kierunków medycznych przeszukujący piśmiennictwo naukowe samodzielnie znajdowali publikacje o charakterze rekomendacyjnym (position statement) sprzed pandemii SARS-CoV-2 wskazujące na konieczność noszenia maseczek chirurgicznych w stanach zagrożenia epidemią wirusa atakującego układ oddechowy, wyposażenia profesjonalistów medycznych w środki ochrony osobistej jak gogle i przyłbice [2], na co zapotrzebowanie o charakterze powszechnym stanowiło „odkrycie” na przełomie lutego i marca 2020 r. w polskim systemie ochrony zdrowia. Zaskoczenie najwyższych państwowych decydentów epidemią wywołaną przez koronawirusa i brak zdecydowanych działań po pierwszych relacjach z Wuhan w styczniu 2020 r. studenci boleśnie konfrontowali z apelami o zapobieganie transmisji wirusów z nietoperzy na ludzi i nie-nowinkarskim podejściem do infekcyjnych chorób w modelu „One Health” Światowej Organizacji Zdrowia $[3,4]$. Już w wieloośrodkowym badaniu amerykańsko-brytyjsko-chińskim, przeprowadzonym przez Li i wsp. [3] w latach 2015-2017, pytano mieszkańców prowincji Yunan nie tylko czy jedzą nietoperze, ale czy podejmują środki ostrożności jak założenie maseczek i rękawiczek (!) podczas zakupów na „wet markets”, co deklarowało $7,1 \%$ respondentów. Słusznie kontestujący przygotowanie merytoryczne decydentów i ich doradców studenci, zamknięci w domach, są dodatkowo obciążeni przez własnych bliskich, którzy traktują ich przynajmniej po części jako osoby powiązane z krytycznie ocenianym sektorem ochrony zdrowia.

Nie ulega wątpliwości, że nierealne byłoby oczekiwanie niezawodnego przygotowania na taką pandemię jak obecna, ale na pewno część serwowanego chaosu przez zarządzających sytuacją kryzysową była do uniknięcia. Wcześniejsze doświadczenia pokonywania SARS nie zostały szeroko spopularyzowane [5]. Historycy są zgodni, że żniwo hiszpanki miało swe źródło w nieuzasadnionym optymizmie ówczesnych ekspertów zamiast skupieniu się na pozyskaniu stałej uwagi społeczeństwa celem modyfikacji zachowań według rekomendowanego modelu profilaktyki [6]. Wirus SARS-CoV-2 jest cały czas poznawany, jak i sposoby oddziaływania na społeczeństwo, by wielokierunkowo przezwyciężyć kryzys generowany przez masowe zachorowania na COVID-19 [7]. Wyścig w kierunku opra- cowania szczepionek i wykorzystania leków już istniejących oraz wynalezienia nowych to najbardziej oczywiste aktywności. Obarczone one będą i ślepymi zaułkami, na co jest ogólne przyzwolenie [7]. Nowoczesne społeczeństwa przełomu XX i XXI wieku koncentrowały się głównie na wzroście dobrobytu materialnego, a pandemia kształtuje nową "generację koronawirusową", silnie zauważającą własne potrzeby duchowe i znaczenie kontaktów międzyludzkich [8]. Ostatnio Olga Tokarczuk podsumowała „Rezultatów pandemii jest w końcu wiele i są one różnorodne. Najważniejszym jednak wydaje mi się złamanie głęboko uwewnętrznionej narracji, że kontrolujemy świat i jesteśmy panami stworzenia" [9].

\section{Mówienie o pandemii językiem przyjaznym}

Twórcy muzyki, m.in. reagge, pokazali jak w udany sposób oswajać problemy związane z egzystencją w czasie pandemii [10]. Na Dalekim Wschodzie szeroko pojęty sektor zdrowia publicznego w walce z pandemią wykorzystuje nowe sposoby przekazywania zaleceń, różniące się co do formy od oficjalnych nakazowych komunikatów. Ciekawe zjawisko stanowi wykorzystywanie tradycyjnej twórczości słowno-muzycznej mniejszości językowo-etnicznych [11]. Klasyczną chińską poezję uznaje się za ważne narzędzie w walce o dobrostan psychiczny społeczeństw Korei Południowej, Japonii i Chin, które wydają się odnosić sukcesy w walce z drugą jesienną falą światowej pandemii w 2020 r. [12]. Dążenie do spokoju wewnętrznego, pojednania z Bogiem dla wierzących, jest ważne w przypadku bardzo namacalnego zagrożenia życia człowieka wskutek choroby [13]. Co interesujące, na Dalekim Wschodzie wdraża się nowatorskie terapie medyczne i równoczasowo wspiera się psychikę chorych oraz daje nadzieję na powstrzymanie choroby za pomocą rozwiązań zaczerpniętych z tradycyjnej chińskiej medycyny, które dawały poczucie sprawstwa nawet na początku pandemii w Wuhan $[11,12,14]$.

Wstępne raporty psychologów wskazują, że ze stresem w czasie pandemii lepiej radzą sobie czytelnicy horrorów i opisów zagłady ludzkości [15]. Poszukujący i wcielający nowe rozwiązania zazwyczaj mieli większe szanse przetrwania niż bierni bohaterowie utworów literackich, co po lekturze motywuje do aktywności w przypadku osobistego doświadczania katastrofy. Dla studentów kierunków medycznych, którzy osobiście zderzyli się z takimi wyzwaniami jak przebywanie wizolacji, nauczaniezdalne, duża płynność zaleceńzwiązanych z rozprzestrzenianiem się wirusa SARS-CoV-2 i niejednokrotnie mocno nadwyrężone zaufanie do przedstawicieli medycznego świata nauki, podobnie jak i dla innych uczących się młodych ludzi, wydaje się celowe znalezienie bezpiecznego „laboratorium myślo- 
wego" [16, 17]. Psychiatrzy dla zachowania dobrostanu zalecają świadome ustalanie rytmu dobowego, ale i poszukiwanie źródeł inspiracji oraz radości, pozostawanie uważnymi, czemu może służyć odpowiedni dobór lektur [1]. Pandemia COVID-19 jest traumatyczna, ale nie musi stanowić kulturowej traumy, co wnikliwie analizowano w krajach o różnym przebiegu pierwszej fali zakażeń i zamożności obywateli, jak Grecja i Szwecja [18].

\section{Próba wskazania tematycznej prozy na czas pandemii}

Izolacja może sprzyjać czytelnictwu literatury pięknej, która spełnia od dawna ważną rolę w edukacji medycznej i rozwijaniu kompetencji zawodowych [19, 20]. Lektura prozy poświęconej fikcyjnym epidemiom stanowi interesujące „laboratorium myślowe” dla studentów kierunków medycznych. Pokazuje kunszt i ograniczenia wyobraźni pisarzy, pośrednio dając zwiększony kredyt zaufania, z prawem do pomyłek, współczesnym ekspertom, którzy usiłują przewidywać kierunki rozwoju pandemii. Porównania epidemii z kart powieści i obecnej pandemii uwidaczniają różnorodność priorytetów ludzi w kryzysie. Burzliwy czas obnaża fałszywą stabilność wielu dotychczasowych fundamentów społeczeństw, na co wskazują przenikliwe autorytety moralne jak Papież Franciszek [8, 21]. Lektura „Dżumy” („La Peste”) Alberta Camusa, „Króla Leara” („King Lear”) i Księgi Hioba w czasie pandemii to ciekawe wyzwanie intelektualne dla osób z przygotowaniem filozoficznym, ale „laboratorium myślowego” dla przeciętnych studentów można upatrywać w łatwiejszej prozie i poezji [21, 22].

W 1842 r. Edgar Allan Poe (1809-1849) stworzył w „Masce śmierci szkarłatnej” (,The Masque of the Red Death") ciekawą alegorię o próbach uniknięcia zarazy. W powieści historycznej „Narzeczeni” („,I promessi sposi”) Alessandro Manzoni (1785-1873) opisał epidemię, która nawiedziła Lombardię w 1630 r., pod ówczesną okupacją hiszpańską, a obecnie region ten, wyróżniający się zamożnością i doskonałym systemem opieki medycznej, stanowi część Włoch paradoksalnie najbardziej dotkniętą przez COVID-19 [23]. Powieść Manzoniego przetłumaczyły na język polski: Maria Obrąpalska w 1882 r. i Barbara Sieroszewska w 1958 r. [24].

„Szkarłatna dżuma” („The Scarlet Plague”) napisana w 1912 r. przez Jacka Londona (1876-1916) wydaje się idealną pozycją dla studentów sfrustrowanych i zawiedzionych brakiem szybkiego sukcesu medycyny w walce $z$ pandemią. Przedwojenne polskie wydania noweli, w tym w ramach Biblioteki Powieściowej Towarzystwa Wydawniczego „Rój”, są trudno dostępne, ale w PRL ukazała się ona w zbiorku opowiadań fantastyczno-naukowych wydawnictwa Czytelnik w nakładzie 50 tys. egzemplarzy i jako oddzielna pozycja w 1994 r. [25,
26]. London stworzył futurystyczną opowieść jeszcze przed zbudowaniem pierwszego mikroskopu elektronowego, umożliwiającego zobaczenie wirusów. Sprawcą epidemii uczynił bakterie (,bakteria jest tak mała, że nie można jej zobaczyć"), po zarażeniu człowieka namnażające się skrycie i prowadzące do nieuniknionej śmierci („Twarz i całe ciało stawało się szkarłatne w przeciągu godziny"). Pojęcia dystansu społecznego wprost nie zdefiniował, ale stwierdzał „Im ciaśniej tłoczyli się ludzie - tem straszniejsze przychodziły choroby”, ,...jedyna rzecz, którą powinniśmy zrobić - to oddzielenie siebie i naszej rodziny w jakiemś bezpiecznem i ustronnem miejscu". Kilka lat przed napisaniem noweli London obserwował, jak niechęć kalifornijskiego gubernatora Henry'ego Gagea do utraty zysków z handlu uniemożliwiła wczesne powstrzymanie rozprzestrzeniania się dżumy w San Francisco [27]. Wymyślona przez Londona pandemia wybuchła w 2013 r., początkowo dotyczyła odosobnionej potężnej aglomeracji (San Francisco) i „,nikt nie przejął się zbytnio ową wiadomością”, a kilkadziesiąt lat później, w 2073 r. jeden z nielicznych ocalałych - akademik James Howard Smith, już jako starzec, opowiadał chłopcom, wiodącym neo-neolityczny żywot pasterzy kóz, o przebiegu katastrofy z eksplozją bandytyzmu po organizacyjnym upadku państwa. Kunszt wyobraźni Londona polega na wymyśleniu świata z początku XXI wieku m.in. jako globalnej wioski z powszechnie dostępną komunikacją lotniczą i telefoniczną („w owych czasach umieliśmy rozmawiać zarówno przez powietrze, jak przez druty”) i wysokim zaufaniem do nauki [28]. W noweli doskwiera skurczenie się aparatu pojęciowego ludzi urodzonych już po katastrofie. W czasie, kiedy u chorych na COVID-19 jest częsta utrata smaku i węchu, emocjonujące skojarzenia budzi kładzenie nacisku przez pisarza na panujący przed klęską dobrobyt. „Myślę czasami, że najbardziej cudowną koroną naszej wspaniałej cywilizacji była właśnie żywność - niezmierna tej żywności obfitość, nieskończona rozmaitość, niewiarygodne wyszukanie." Warto zwrócić uwage, że London, znany z lewicowych przekonań, najprawdopodobniej nieprzypadkowo wybrał rok 2073 na czas akcji swojej opowieści. W nieprzetłumaczonej na język polski, jednej z pierwszych apokaliptycznych nowel „The Last Man” (1826 r.), pierwotnie odrzuconej przez krytyków literackich, a admirowanej po II wojnie światowej [29], Brytyjka Mary Shelley (1797-1851), znana głównie jako autorka „Frankensteina”, opisywała abdykację króla Anglii pod naciskiem społeczeństwa właśnie w 2073 r. Lektura noweli Londona mobilizuje do porzucenia postawy biernej kontestacji i walki z pandemią o zachowanie znanego nam świata. W przypadku przegranej, wygodnego i dostatniego sposobu życia, nam znanego, już nie będzie. Podobne przesłanie ma 
powieść „Stacja jedenaście” („Station Eleven”) z 2014 r. Kanadyjki Emily St.John Mandel (ur. 1979) [30]. Epidemia „grypy gruzińskiej” szybko rozprzestrzeniała się po świecie. Początkowo do szpitali trafiali pacjenci mający bardzo podobne objawy i często po podróży tym samym samolotem. Umierali pracownicy szpitali. Pisarka bezpośrednio odwołała się do SARS. Szkolący się na ratownika medycznego, Jeevan Chaudhary zdaje sobie sprawę, że ta choroba „...będzie wyznacznikiem życia przed i po. Będzie cienką linią dzielącą jego życie na pół." Przeżyli nieliczni, ludzkość nie cofnęła się drastycznie, ale realia życia zmieniły się. Poetycka wizja świata z pragnieniem sztuki i więzi międzyludzkich mocno zapada w pamięć.

Postać wykształconego we Francji dr. Juvenala Urbino de la Calle, który „zasłynął w kraju /tj. Kolumbii przypis autora/, powstrzymując na czas, dzięki nowym i drastycznym metodom, ostatnią epidemię cholery...", z „Miłości w czasach zarazy” („El amor en los tiempos del cólera") Gabriela G. Márqueza (1927-2014) ma duży potencjał zaciekawiania czytelnika. Ojcem doktora Urbino był też lekarz „raczej ofiarny niż znamienity, zmarł podczas/wcześniejszej - przypis autora/epidemii cholery azjatyckiej”. Można dyskutować o zasadności bycia przez dr. Urbiono „bezwzględnym krytykiem lekarzy, wykorzystujących swój zawodowy prestiż do kariery politycznej" i transponowania tej rekomendacji z XIX wieku do współczesnej Polski. Powieść Márqueza jest jednak przede wszystkim wielkim hołdem dla miłości bez odmawiania do niej prawa ludziom starym [31]. Ma to szczególny wymiar w pandemii COVID-19, kiedy niezrozumienie potrzeby ponoszenia wyrzeczeń przez jednostkę i całe społeczności celem ochrony ludzi w podeszłym wieku można by nazwać ich wykluczaniem z uniwersalnego prawa do miłości. Warto przytoczyć wnikliwą obserwację Tokarczuk „Coraz wyraźniej i głośniej werbalizowany staje się konflikt między starymi i młodymi, widać to szczególnie w przypadku pandemii, którą demonizują jeszcze różnice biologicznej odporności na wirusa... Wnuków i dziadków dzieli dziś więcej niż kiedyś mieszkańców Nowego Jorku i Sandomierza." [9]. Można doszukać się i wielu innych paraleli między powieścią kolumbijskiego noblisty, reprezentującą magiczny realizm, a obecną pandemią [32]. Sam tytuł dzieła jest niejednoznaczny, gdyż hiszpańskie słowo cólera oznacza, podobnie jak w języku polskim, chorobę zakaźną cholerę jak i gniew. W piśmiennictwie naukowym znajdują się ciekawe dowody twórczej inspiracji „Miłością w czasach zarazy" profesjonalistów medycznych [33, 34], a między nimi i pielęgniarek [35]. Niestety jakość tłumaczenia „Stacji jedenaście” i „Szkarłatnej dżumy" nie jest porywająca, co szczególnie kontrastuje z pięknymi przekładami Bolesława Leśmiana - „Maski śmierci szkarłatnej” i C. Marrodána Casasa - „Miłości w czasach zarazy”, wielokrotnie wznawianej w naszym kraju po pierwszej edycji w 1994 r. [36].

Wątek wykorzystywania szczepionek w sposób destrukcyjny występuje m.in. w „Pielgrzymie” („I Am Pilgrim”) Terry'ego Hayesa (ur. 1951) [37]. Główny bohater na ostatnich kartach wielowątkowej powieści demaskuje umieszczenie wirusa ospy w szczepionkach przeciwgrypowych tuż przed sezonem szczepień. Wielokrotnie śmiercionośny wirus pojawiał się także jako konceptualny rekwizyt w bestsellerach ostatnich lat jak "Inferno” Dana Browna (ur. 1964) czy dystopijna trylogia „Oryks i Derkacz/Rok potopu/MaddAddam” („Oryx and Crake/ The Year of the Flood/MaddAddam") Kanadyjki Margaret Atwood (ur. 1939). Dla równowagi warto zwrócić uwagę jak zaskakująco mało jest nowel poświęconych hiszpance, napisanych przez świadków tamtej pandemii, co nazwano amnezją postpandemiczną [6]. Do nielicznych wyjątków należy "They Came Like Swallows” z 1937 r., autobiograficzna powieść o Środkowym Zachodzie USA w 1918 r., widzianym oczami ośmioletniego dziecka, Williama Maxwella (1908-2000) [6]. Za to w wielu krajach historycy medycyny interesująco analizowali niefarmakologiczne sposoby walki z hiszpanką, wzorując się na pionierskiej pracy Markela i wsp. [38, 39].

Epidemia przywleczonej z Azji ospy prawdziwej, wygaszonej w ciągu 25 dni, którą opłaciło śmiercią czworo lekarzy i pielęgniarek we Wrocławiu w 1963 r. [39, 40], była przyczynkiem zbeletryzowanej reporterskiej opowieści „Zaraza” Jerzego Ambroziewicza (1931-1995) [41], opublikowanej w 1965 r. i dokumentalnej książki „Ospa 1963. Alarm dla Wrocławia”, będącej zwieńczeniem wieloletnich kwerend archiwów, uczestnika tamtych zdarzeń, lekarza zakaźnika, a zarazem poety i publicysty Jerzego B. Kosa (1931-2018) [42].

Epidemie często inspirowały filmowców i twórców gier komputerowych [43], co tematycznie wykracza poza zaplanowany zakres artykułu. Warto jednakże wspomnieć, że wiele anglojęzycznych apokaliptycznych powieści nieprzetłumaczonych na język polski, dla których inspiracją była m.in. „Szkarłatna dżuma”, jak np. „Earth Abides” z 1949 r. Georga R. Stewarta (1895-1980) i „I Am Legend” z 1954 r. Richarda Mathesona (19262013), zekranizowano.

\section{Spostrzeżenia końcowe}

Na podstawie licznych, z założenia interdyscyplinarnych [44], dyskusji prowadzonych ze studentami kierunków medycznych za szczególnie inspirujące i stanowiące przyczynek do „laboratorium myślowego” można uznać trzy z przedstawionych utworów. „Szkarłatna dżuma” będzie odpowiednia dla osób lubiących dość surową narrację reporterską, „Stacja jedenaście” pochłonie po- 
szukujących wizji świata z kończącym się biznesem telewizyjnym, Internetem i transportem lotniczym, a żelazną pozycję dla wielbicieli kunsztownej literatury z nurtu realizmu magicznego, z li tylko tematem epidemii jako pretekstem, stanowi „Miłość w czasach zarazy”. Powieść Márqueza bywa także wskazywana w przewodnikach lektur, które mogą stricte służyć uwrażliwieniu estetycznemu studentów kierunków medycznych jak i ich akademików [45]. Trudne do okiełznania rozprzestrzenianie się wirusa zachęca do refleksji, kim jesteśmy jako społeczeństwo, i do nabywania umiejętności budowania relacji o charakterze profilaktycznym oraz terapeutycznym $[1,46,47]$. Obecna pandemia otwiera także nową płaszczyznę w dyskusji o płciowości człowieka [48]. Co interesujące, w dziełach literackich z wątkiem zarazy nie pojawiał się dotychczas trop zależności podatności na ciężki przebieg choroby od płci.

Wskazany jest wysiłek doboru literatury pięknej, i jego walidacji, zarówno celem wzmacniania umiejętności radzenia sobie czytelnika ze stresem w czasie pandemii jak i nabywania cech, które uznamy za pożądane podczas wykonywania zawodu po pandemii przez obecnych studentów kierunków medycznych [19, $46,49,50]$. Uzasadniony głęboki krytycyzm wobec systemu ochrony zdrowia u kontestujących młodych ludzi nie powinien osłabiać ich fascynacji medycyną. Dezaprobata Londona wobec wysoce uprzywilejowanej kasty najzamożniejszych i jej niewrażliwości na problemy społeczeństwa jako całości w „Szkarłatnej dżumie” stanowi ciekawy pomost do obecnie toczącej się dyskusji o syndemii, czyli pandemii SARS-CoV-2 z szerokim uwzględnieniem pozamedycznych uwarunkowań [47].

\section{Piśmiennictwo}

1. Peteet JR. COVID-19 anxiety. J Religion Health 2020; 59: 2203-2204.

2. Park S, Park JY, Song Y, How SH et al. Emerging respiratory infections threatening public health in the Asia-Pacific region: A position paper of the Asian Pacific Society of Respirology. Respirology 2019; 24: 590-597.

3. Li H, Mendelsohn E, Zong C, Zhang W et al. Human-animal interactions and bat coronavirus spillover potential among rural residents in Southern China. Biosafety Health. 2019; 1: 84-90.

4. McCloskey B, Dar O, Zumla A, Heymann DL. Emerging infectious diseases and pandemic potential: status quo and reducing risk of global spread. Lancet Infect Dis 2014; 14: 1001-1010.

5. Hsin DH, Macer DR. Heroes of SARS: professional roles and ethics of health care workers. J Infect Dis 2004; 49: 210-215.

6. McKnight Nichols C, Bristow N, Ewing ET, etal. Reconsidering the 1918-19 influenza pandemic in the age of COVID-19. J Gilded Age Progressive Era 2020; 19: 642-672.

7. Charlier P, Donell S, Lippi $D$, bet al. Hydroxy-chloroquine to treat COVID-19 - infected patients: Some lessons from medical anthropology and history of medicine. Ethics Med Publ Health. 2020; 15: 100587.

8. Kowalczyk O, Roszkowski K, Montane X, et al. Religion and faith perception in a pandemic of COVID-10. J Religion Health. 2020; 59: 2671-2677.

9. Tokarczuk O. Człowiek na krańcach świata. Polityka (tygodnik) 2020, nr 40(3281): 24-30.

10. https://news.wbfo.org/post/new-study-coronavirus-songsafrica-looks-impact-music-message (dostęp 30.11.2020).

11. Bai GH. Fighting COVID-19 with Mongolian fiddle stories. Multilingua 2020; 39(5): 577-586.

12. Chen X. Fighting COVID-19 in East Asia: The role of classical Chinese poetry. Multilingua 2020; 39(5): 565-576.

13. Steinhauser KE, Christakis NA, Clipp EC, et al. Factors considered important at the end of life by patients, family, physicians, and other care providers. JAMA 2000; 284: 2476-2482.

14. Ni L, Zhou L, Zhou M, et al. Combination of western medicine and Chinese traditional patent medicine in treating a family case of COVID-19 in Wuhan. Front Med. 2020; 14(2): 210-214.

15. Scrivner C, Johnson JA, Kjeldgaard-Christiansen J, Clasen M. Pandemic practice: Horror fans and morbidly curious individuals are more psychologically resilient during the COVID-19 pandemic. Personality Individual Differences. 2020; 168: 110397.

16. Warzocha A. From exclusion to inclusion: Audiovisual identity literature of young students. Elem Edu Theory Pract. 2020; 57(3): 113-125.

17. Malikova DM. Reading and Internet networks during pandemic. Int Sci Rev. 2020; 72(12): 38-40.

18. Demertzis N, Eyerman R. Covid-19 as cultural trauma. Am J Cult Sociol 2020 doi: 10.1057/s41290-020-00112-z.

19. Kidd $D$, Castano $E$. Reading literary fiction improves theory of mind. Science 2013; 342(6156): 377-380.

20. Hozyasz KK. Rola literatury pięknej w edukacji medycznej. Piel Zdr Publ. 2020; 10(3): 171-177.

21. Susanto E. Reading the Book of Job and Camus's La Peste during COVID-19. Indonesian J Theology 2020; 8(1): 8-27.

22. Sinha A. King Lear under COVID-19 lockdown. JAMA 2020; 323(18): 1758-1759.

23. CastaldiS, Maffeo M, RivieccioBA, etal. Monitoring emergency calls and social networks for COVID-19 surveillance. To learn for the future: The outbreak experience of the Lombardia region in Italy. Acta Biomed. 2020; 91(9S): 29-33.

24. Manzoni A. Narzeczeni. Państwowy Instytut Wydawniczy, Warszawa 1958.

25. London J. Szkarłatna dżuma. Opowiadania fantastyczno-naukowe. Czytelnik, Warszawa, 1978.

26. London J. Szkarłatna dżuma. Oficyna Wydawnicza SAWA, Warszawa, 1994.

27. Kalisch PA. The black death in Chinatown; plague and politics in San Francisco 1900-1904. Ariz West. 1972; 14(2): 113-136.

28. Riva MA, Benedetti M, Cesana G. Pandemic fear and the literature: observations from Jack London's The Scarlet Plague. Emerg Infect Dis. 2014; 20(10): 1753-1757.

29. Bennet BT. Radical imaginings: Mary Shelley's "The Last Man". Wordsworth Circle. 1995; 26(3): 147-152.

30. St. John E. Stacja jedenaście. Wydawnictwo Papierowy Księżyc, Słupsk, 2015.

31. Clarfield M. Novel medicine: Love in the Time of Cholera. J Royal Soc Med. 2007; 100: 107. 
32. Muenke M. Love in the time of COVID-19. Am J Med Genet A. 2020; 182(6): 1299-1301.

33. Baňos JE. El valor de la literatura en la formación de los estudiantes de medicina. Educ Medica. 2003; 6(2): 93-99.

34. Toledo-Pereyra LH. Medicine, Gabriel Garcia Márquez, and Love in the Time of Cholera. J Invest Surg. 2008; 21(1): 5-8.

35. Boruń T. Rola pielęgniarki w opiece paliatywnej i hospicyjnej - opis przypadku Adama. Piel Zdr Publ. 2011; 1(3): 289-295.

36. Marquez GG. Miłość w czasach zarazy. Wydawnictwo Literackie „Muza”, Warszawa, 1994.

37. Hayes T. Pielgrzym. Dom Wydawniczy REBIS, Poznań, 2014.

38. Markel H, Lipman HB, Navarro JA, et al. Nonpharmaceutical intervensions implemented by US cities during the 19181919 influenza pandemic. JAMA. 2007; 298(6): 644-654.

39. Brown J. Grypa. Sto lat walki. Wydawnictwo Uniwersytetu Jagiellońskiego, Kraków, 2019.

40. Żuk P, Żuk P. One of the recent attacks of smallpox in Europe: A massive vaccination campaign during the epidemic in Wrocław in 1963.Vaccine 2019; 37(41): 6125-6131.

41. Kraska-Lewalski A. "Czarna Pani we Wrocławiu..." Epidemia ospy prawdziwej w 1963 r. w archiwum i obiektywie Józefa Bakalarskiego operatora Polskiej Kroniki Filmowej. Czasopismo Zakładu Narodowego im. Ossolińskich 2019; 30: $153-19$

42. Ambroziewicz J. Zaraza. Książka i Wiedza, Warszawa, 1965.

43. Kos JB. Ospa 1963. Alarm dla Wrocławia. Wydawnictwo Warstwy, Wrocław 2017.

44. Podomarof P. Krótko o obecności moru. Colloquia Anthropologica et Communicativa. 2012; 5: 513-524.

45. Sajdak A. Interdyscyplinarność dydaktyki akademickiej. Roczn Komisji Nauk Pedagog. 2016; 69: 5-16.
46. Alerm González A, González Pérez U. Apreciación estética y artistica en el proceso enseňanza-apredizaje de la medicina. Educ Med Super. 2014; 28(4): 766-780.

47. Oatley K. Fiction: simulation of social worlds. Trends in Cogn Sci. 2016; 20(8): 618-628.

48. Horton R. Offline: COVID-19 is not a pandemic. Lancet. 2020; 396(10255): 874.

49. Jahme C, Kutschera U. Biological sex and Covid-19: Science versus ideology. J Behav Health. 2020; 9(2): 1-6.

50. Somerville D, Keeling J. A practical approach to promote reflective practice within nursing. Nursing Times. 2004; 100(12): 42-45.

51. Cox A, Brewster L. Library support for student mental health and well-being in the UK: Before and during the COVID-19 pandemic. J Acad Librarianship. 2020; 56(6): 102256.

Artykuł przyjęty do redakcji: 31.12.2020.

Artykuł przyjęty do publikacji: 25.06.2021.

Źródło finansowania: Praca nie jest finansowana z żadnego źródła. Konflikt interesów: Autor deklaruje brak konfliktu interesów.

Adres do korespondencji:

Kamil Konrad Hozyasz

ul. Sidorska 95/97

21-500 Biała Podlaska

e-mail: khozyasz@gmail.com

Wydział Nauk o Zdrowiu, Państwowa Szkoła Wyższa im. Papieża Jana Pawła II w Białej Podlaskiej 